\title{
PODSTAWY PRAWNE GEOINFORMACYJNEGO WSPARCIA OCEN ODDZIAŁYWANIA NA ŚRODOWISKO W POLSCE
}

\section{LEGAL BASIS FOR THE GEOINFORMATIONAL SUPPORT OF ENVIRONMENTAL IMPACT ASSESSMENT IN POLAND}

http://dx.doi.org/10.12775/PPOS.2015.031

\section{STRESZCZENIE}

Organy administracji zaangażowane w ocenę oddziaływania na środowisko planowanego przedsięwzięcia winny korzystać z informacji i metod weryfikacji o jak najwyższej jakości czy pewności. Współcześnie rozwijające się społeczeństwo geoinformacyjne dysponuje

* Doktorant w Zakładzie Geoinformacji, Instytut Geoinformacji i Geoekologii, Wydział Nauk Geograficznych i Geologicznych, Uniwersytet im. Adama Mickiewicza w Poznaniu; radca prawny, biegły w zakresie ochrony środowiska przy Sądzie Okręgowym w Poznaniu. 
rozwiązaniami spełniającymi wymienione wyżej wymagania stawiane instytucjom. Dlatego też istotnym jest wypracowanie zasad wsparcia administracji rządowej oraz samorządowej w postępowaniach administracyjnych systemami geoinformacyjnymi, które dostarczają danych, procedur i narzędzi do obiektywizacji podejmowanych decyzji środowiskowych.

\section{Słowa kluczowe}

Oceny oddziaływania na środowisko; geoinformacja; GIS; Dyrektywa INSPIRE.

\section{ABSTRACT}

Environmental impact assessment (EIA) is an instrument ensuring environmental protection at the stage of the decision-making process preceding investment implementation. It enables the preparation of an investment process in such a way that the implementation and functioning of the investment has the lowest negative impact on the geographical environment possible negative. After World War II, economic growth became very intensive. Only the technical and economic aspects of investment enterprises were analysed during the design of new investments. The impact of new, large-scale investments on the environment in various parts of the world was so significant, that it caused concern for the balance in the environment and its functioning, not only on a local, but also on a global scale (Synowic, Rzeszot 1995). This concern resulted in, among others, the development of legislation on environmental impact assessment.

Impact assessments may refer to direct undertakings (which served as prototypes for international and European solutions), but also to programmes, plans, policies, and draft laws (as was provided for by the US legislation and the European legislation since 2001). The article does not discuss the issue of strategic environmental impact assessment of draft documents (programmes, plans, and policies), only signalling their existence. The development of environmental impact assessment and legal basis for spatial information infrastructure presented in the article point to the need of permanently including geoinformation systems into administrative proceedings concerning assessments or decisions motivated by environmental factors. The geoinformational support functioning pursuant to the INSPIRE 
directive will enable administrative bodies to make decisions based on reliable spatial information with legal basis.

\section{Keywords}

Environmental impact assessment; geoinformation; GIS; INSPIRE Directive.

\section{UWAGI WSTĘPNE}

Ocena oddziaływania na środowisko (OOŚ) jest instrumentem służącym zapewnieniu ochrony środowiska jeszcze na etapie procesu decyzyjnego poprzedzającego realizacje inwestycji. Ma ona umożliwić przygotowanie procesu inwestycji w taki sposób, aby realizacja i funkcjonowanie miało jak najmniejszy negatywny wpływ na środowisko geograficzne.

Po II Wojnie Światowej miał miejsce niezwykle intensywny rozwój gospodarczy. Przy projektowaniu nowych nakładów analizowano jedynie techniczną oraz ekonomiczną stronę przedsięwzięć inwestycyjnych. Skutki oddziaływania nowych, wielkich inwestycji na środowisko w różnych częściach świata przybrały takie rozmiary, że wywołały niepokój o spowodowanie zakłóceń równowagi środowiska, a także jego funkcjonowania nie tylko w ograniczonej skali lokalnej, ale również w skali globalnej (Synowic, Rzeszot 1995). Efektem powyższych wątpliwości był m.in. rozwój prawodawstwa w zakresie ocen oddziaływania na środowisko.

Oceny oddziaływania mogą się odnosić do przedsięwzięć bezpośrednich (co stanowiło pierwowzór rozwiązań międzynarodowych i europejskich), ale także do programów, planów, polityk, a także projektów aktów prawnych (tak jak to przewidziano w ustawodawstwie Stanów Zjednoczonych oraz europejskim od $2001 \mathrm{r}^{1}$ ). W niniejszym artykule przedstawiono

1 Uchwalenie Dyrektywy 2001/42/WE Parlamentu Europejskiego i Rady z dnia 27 czerwca 2001 r. w sprawie oceny wpływu niektórych planów i programów na środowisko, Dz. Urz. UE L 197 z 21.07.2001, s. 30. 
rozwój uregulowań OOŚ oraz uzasadnienie prawne trwałego wprowadzenia do nich narzędzi geoinformacyjnych. W piśmie pominięto problematykę strategicznych ocen oddziaływania na środowisko projektów dokumentów (programów, planów i polityk), sygnalizując jedynie fakt ich istnienia.

\section{MIĘDZYNARODOWE UWARUNKOWANIA WPROWADZENIA OOŚ}

W dniu 1 stycznia 1970 r. Prezydent Stanów Zjednoczonych Richard Nixon podpisał Ustawę o krajowej polityce środowiskowej (National Environmental Policy Act of 1969), uchwaloną w grudniu 1969 r. przez Kongres Stanów Zjednoczonych. Ustawa zobowiązuje, aby polityka, przepisy i prawa publiczne w Stanach Zjednoczonych były interpretowane, jak też ustalane zgodnie z jej zasadami. Dla zapewnienia tego celu wprowadzono procedury przygotowania oceny oddziaływania na środowisko (EA) oraz oświadczenia w sprawie oddziaływania na środowisko (EIS). EA i EIS zawierają opisy, a także oceny dotyczące wpływu na środowisko proponowanych działań. Oceny oddziaływania na środowisko dotyczyły projektów inwestycji, programów, planów, polityk, projektów aktów prawnych podejmowanych przez wszystkie organy rządu federalnego. EA ma od początku otwarty charakter, jak również uwzględnia udział społeczeństwa w podejmowaniu decyzji (Ciechelska 2009).

Ze względu na swą doniosłość oraz fakt, iż procedura oceny oddziaływania na środowisko dotyczyła wszystkich agencji federalnych władzy wykonawczej (ustawy nie stosuje się do prezydenta, Kongresu czy sądu federalnego) nazywana jest ona Wielką Kartą prawa ochrony środowiska - „Magna Carta” of environmental laws (Council on Environmental Quality 2007).

$\mathrm{Na}$ gruncie międzynarodowym pierwszym znaczącym wydarzeniem była XXIII Sesja Zgromadzenia Ogólnego Narodów Zjednoczonych z dnia 3 grudnia 1968 r., na której zagadnienia relacji „człowiek i środowisko” znalazły się w głównym 3/2015 nurcie zainteresowania (Zbierska 2007). Kolejnym krokiem mi- 
lowym była Konferencja Narodów Zjednoczonych w Sztokholmie w sprawie środowiska, zakończona podpisaniem Deklaracji Sztokholmskiej z dnia 16 czerwca 1972 r. W podpisanej deklaracji zawarto szereg zaleceń $\mathrm{w}$ realizacji polityki ochrony środowiska. Wśród 26 zasad deklaracji uzgodniono między innymi, że:

- racjonalne planowanie (przestrzenne) winno być podstawowym instrumentem godzenia wszelkich konfliktów między rozwojem a ochroną środowiska;

- powinno być tak realizowane, aby przynosić maksymalne efekty, zgodne z potrzebą ochrony i poprawy naturalnego środowiska dla dobra ludzkości.

Wśród zaleceń wypracowanych $\mathrm{w}$ trakcie konferencji wskazano, aby w poszczególnych krajach zajęto się ustaleniem zasad polityki ochrony środowiska, określeniem procedury ocen oddziaływania na środowisko oraz stworzeniem organów wyspecjalizowanych w sprawach ochrony środowiska. Niedostatki polityki ochrony środowiska, jej dotychczasowych narzędzi - nakierowanie na łagodzenie skutków szkodliwej działalności człowieka, a nie na zapobieganie im oraz dbałość o poszczególne komponenty środowiska, brak kompleksowego ujęcia środowiska wywołały potrzebę wprowadzenia oceny oddziaływania na środowisko jako instrumentu prewencyjnego, który powinien być powszechny.

Działania międzynarodowe implikowały konieczność wprowadzania odpowiednich regulacji w zakresie oceny oddziaływania na środowisko zarówno na gruncie wspólnotowym, jak i prawodawstw poszczególnych krajów, w tym Polski.

\section{OCENA ODDZIAŁYWANIA NA ŚRODOWISKO W EUROPIE}

Na gruncie europejskim po raz pierwszy procedura oceny oddziaływania na środowisko planowanych przedsięwzięć (Environmental lmpact Assessment, EIA) uregulowana została w Dyrektywie Rady 85/337/EWG z dnia 27 czerwca 1985 r. 
w sprawie oceny skutków wywieranych przez niektóre przedsięwzięcia publiczne oraz prywatne na środowisko naturalne ${ }^{2}$.

W myśl tej dyrektywy przedmiotem oceny oddziaływania na środowisko była analiza potencjalnych, bezpośrednich i pośrednich skutków realizacji przedsięwzięcia w środowisku. Postępowanie w sprawie oceny oddziaływania na środowisko mogło być przeprowadzane odrębnie bądź stanowić element innego postępowania zmierzającego do wydania decyzji określającej lokalizację danego przedsięwzięcia lub pozwalającej na jego realizację.

Informacje dotyczące planowanego przedsięwzięcia zgodnie z powyższą dyrektywą przedstawiane winny być $\mathrm{w}$ formie raportu środowiskowego, na podstawie którego właściwe organy administracji mogą podjąć decyzję w sprawie przedsięwzięcia, zawierającego w szczególności: opis przedsięwzięcia zawierający informacje o miejscu, projekcie i wielkości przedsięwzięcia, opis środków przewidzianych w celu uniknięcia, zmniejszenia oraz - jeżeli to możliwe - naprawienie poważnych niekorzystnych skutków, dane wymagane do rozpoznania, a także oszacowania głównych skutków, które mogą być spowodowane w środowisku przez to przedsięwzięcie, zarys zasadniczych alternatywnych rozwiązań rozważanych przez wykonawcę, łącznie ze wskazaniem głównych powodów dokonanego przez niego wyboru uwzględniającego skutki środowiskowe oraz podsumowanie w języku niespecjalistycznym. Wśród rozwiązań wskazanych w dyrektywie istotnymi kwestiami były również konsultacje $\mathrm{z}$ organami ochrony środowiska i udział społeczeństwa. Celem postępowania z udziałem społeczeństwa winno być stworzenie możliwości wyrażania opinii, jak również składania wniosków w sprawie danego przedsięwzięcia przez wszystkich zainteresowanych. Dyrektywa zawierała również szczegółowe uregulowania dotyczące postępowania w sprawie

2 Dz. Urz. UE L 175 z 5.07.1985, s. 40 z późn. zm.; uchylona Dyrektywą Parlamentu Europejskiego i Rady 2011/92/UE z dnia 13 grudnia 2011 r. w sprawie oceny skutków wywieranych przez niektóre przedsięwzięcia publiczne i prywatne na środowisko, Dz. Urz. UE L 26 z 28.01.2012, s. 1 (dalej cyt.: Dyrektywa 2011/92/UE). 
oceny oddziaływania na środowisko w kontekście transgranicznym przeprowadzanego $\mathrm{w}$ przypadku, gdy realizacja danego przedsięwzięcia powoduje znaczące oddziaływanie na środowisko przekraczające granice jednego państwa.

Obecnie obowiązująca Dyrektywa 2011/92/UE zachowuje zasady i ducha swej poprzedniczki. Uregulowania dyrektywy zostały wdrożone we wszystkich państwach członkowskich Unii Europejskiej.

\section{SYSTEM OCENY ODDZIAEYWANIA NA ŚRODOWISKO W POLSCE}

W Polsce instytucja oceny oddziaływania na środowisko ma swoje początki w Ustawie z dnia 31 stycznia 1980 r. o ochronie i kształtowaniu środowiska ${ }^{3}$. Procedura oceny oddziaływania na środowisko w okresie od 1980 roku do chwili obecnej ulegała w polskim systemie prawnym przeobrażeniom. W fazie początkowej (do roku 1989) na projektancie, a także inwestorze spoczywał generalny obowiązek stosowania procesów technologicznych najmniej uciążliwych dla środowiska oraz racjonalnego rozwiązania problemów postępowania z odpadami i ściekami, w szczególności gospodarczego ich wykorzystania. Ponadto byli oni zobowiązani zapewnić oszczędne korzystanie z terenu potrzebnego dla podejmowanej inwestycji. W przypadku zaś inwestycji mogących zagrozić środowisku wymagane były uzgodnienia z organami administracji państwowej stopnia wojewódzkiego. Tak więc to ów organ miał za zadanie przeanalizowanie projektowanych rozwiązań i wydanie uzgodnienia.

W kolejnym okresie (lata 1989-1998) organy administracji otrzymały wsparcie rzeczoznawców wyznaczanych przez organ, którzy dokonywali oceny w zakresie oddziaływania na środowisko, rozwiązań projektowych inwestycji mogących pogorszyć stan środowiska. W 1998 roku po raz kolejny doko-

3 Dz.U. Nr. 3, poz. 6. 
nano zmian w postępowaniu i wprowadzono instytucję oceny oddziaływania na środowisko, odpowiedniej dla danego etapu inwestycyjnego, sporządzonej na koszt inwestora przez biegłego z listy Ministra Ochrony Środowiska, Zasobów Naturalnych i Leśnictwa (od 01.01.1999 r. biegłego z listy wojewody) ${ }^{4}$. Przedmiotowa ocena była podstawą do dokonania uzgodnienia warunków zabudowy, zagospodarowania terenu oraz projektu budowlanego inwestycji szczególnie szkodliwej dla środowiska, jak też zdrowia ludzi lub inwestycji mogącej pogorszyć stan środowiska, dokonywanego przez wojewodę, a także państwowego terenowego inspektora sanitarnego.

Tak więc w pierwszym okresie to inwestor oraz projektant dostarczał wszelkich wymaganych danych. W drugim, jak też w trzecim okresie wprowadzania ocen oddziaływania na środowisko istotnym był dokument tworzony przez zewnętrznego eksperta niezależnego od inwestora, a także organu administracji.

Począwszy od Ustawy z dnia 9 listopada 2000 r. o dostępie do informacji o środowisku i jego ochronie oraz o ocenach oddziaływania na środowisko ${ }^{5}$, poprzez Ustawę $\mathrm{z}$ dnia 27 kwietnia 2001 r. Prawo ochrony środowiska ${ }^{6}$, aż do obecnie obowiązującej Ustawy z dnia 3 października 2008 r. o udostępnianiu informacji o środowisku i jego ochronie, udziale społeczeństwa w ochronie środowiska oraz o ocenach oddziaływania na środowisko ${ }^{7}$, obowiązują regulacje, w myśl których organy właściwe do przeprowadzenia oceny lub wydania decyzji o środowiskowych uwarunkowaniach otrzymują opracowanie (kartę informacyjną przedsięwzięcia, raport oceny oddziaływania przedsięwzięcia na środowisko albo prognozę oddziaływania na środowisko) o charakterze eksperckim, jak też dokonują jego weryfikacji, a - o ile jest to niezbędne - dokonują konsultacji społecznych.

4 Obecnie brak jest podstaw do prowadzenia przedmiotowych list, a posługiwanie się przez niektóre osoby tą tytulaturą stanowi nadużycie i wprowadza w błąd osoby zapoznające się z opracowaniami.

5 Dz.U. z 2000 r. Nr 109, poz. 1157 ze zm.

6 T.j. z 2013 r., poz. 1232 ze zm.

7 T.j. z 2013 r., poz. 1235 ze zm. (dalej cyt.: u.i.o.ś.). 
Obowiązujące obecnie przepisy u.i.o.ś. wraz z Rozporządzeniem Rady Ministrów z dnia 9 listopada 2010 r. w sprawie przedsięwzięć mogących znacząco oddziaływać na środowisko ${ }^{8}$, regulują sytuacje, w których przed realizacją przedsięwzięcia wymagane jest:

- uzyskanie decyzji o środowiskowych uwarunkowaniach lub

- przeprowadzenie oceny oddziaływania przedsięwzięcia na środowisko (w tym ponownej) albo

- przeprowadzenie oceny oddziaływania przedsięwzięcia na obszar Natura 2000.

Wskazane procedury odnoszą się do przedsięwzięć rozumianych jako zamierzenie budowlane lub inna ingerencja w środowisko polegająca na przekształceniu lub zmianie sposobu wykorzystania terenu, $\mathrm{w}$ tym również na wydobywaniu kopalin.

W ramach przedmiotowych procedur inwestor zobowiązany jest opracować

- kartę informacyjną przedsięwzięcia lub

- raport o oddziaływaniu przedsięwzięcia na środowisko.

Opracowane dokumenty przekazywane są organom właściwym do wydania decyzji o środowiskowych uwarunkowaniach (wójt, burmistrz, prezydent miasta ${ }^{9}$ albo regionalny dyrektor ochrony środowiska ${ }^{10}$ lub Generalny Dyrektor Ochrony

8 Dz.U. z 2013 r. Nr 213, poz. 1397 ze zm.

9 Dla przedsięwzięć niezastrzeżonych dla innych organów. Zob. art. 75 ust. 1 pkt 4 u.i.o.ś.

10 W przypadku: a) będących przedsięwzięciami mogącymi zawsze znacząco oddziaływać na środowisko: dróg, linii kolejowych, napowietrznych linii elektroenergetycznych, instalacji do przesyłu ropy naftowej, produktów naftowych, substancji chemicznych lub gazu, sztucznych zbiorników wodnych, obiektów jądrowych, składowisk odpadów promieniotwórczych; b) przedsięwzięć realizowanych na terenach zamkniętych; c) przedsięwzięć realizowanych na obszarach morskich; d) zmiany lasu, niestanowiącego własności Skarbu Państwa, na użytek rolny; e) przedsięwzięć polegających na realizacji inwestycji w zakresie lotniska użytku publicznego w rozumieniu przepisów Ustawy z dnia 12 lutego 2009 r. o szczególnych zasadach przygotowania i realizacji inwestycji w zakresie lotnisk użytku publicznego; f) inwestycji w zakresie terminalu; g) inwestycji związanych z regionalnymi sieciami sze- 
Środowiska ${ }^{11}$ bądź starosta ${ }^{12}$ ewentualnie dyrektor regionalnej dyrekcji Lasów Państwowych ${ }^{13}$ ) lub organom właściwym do zaopiniowania - regionalnemu albo Generalnemu Dyrektorowi Ochrony Środowiska i Państwowej Inspekcji Sanitarnej. Przepisy ustawy ściśle regulują jakie czynności winny podjąć organy wydające decyzje o środowiskowych uwarunkowaniach lub dokonujące którejś z ocen oddziaływania na środowisko. Zgodnie $\mathrm{z}$ art. 3 ust. 1 pkt 8 i 7 u.i.o.ś. (odpowiednio) obejmują one:

- ocenę oddziaływania przedsięwzięcia na środowisko rozumianą jako postępowanie w sprawie oceny oddziaływania na środowisko planowanego przedsięwzięcia;

- weryfikację raportu o oddziaływaniu przedsięwzięcia na środowisko;

- uzyskanie wymaganych ustawą opinii i uzgodnień;

- zapewnienie możliwości udziału społeczeństwa w postępowaniu;

- ocenę oddziaływania przedsięwzięcia na obszar Natura 2000, rozumianą jako ocena oddziaływania przedsięwzięcia na środowisko ograniczona jest do badania oddziaływania przedsięwzięcia na obszar Natura 2000.

W rozważaniach przyjęto, iż pod pojęciem oceny oddziaływania na środowisko mieszczą się postępowania administracyj-

rokopasmowymi; h) przedsięwzięć polegających na zmianie lub rozbudowie przedsięwzięć wymienionych w lit. a-g, i oraz j; i) przedsięwzięć polegających na realizacji inwestycji w rozumieniu przepisów Ustawy z dnia 8 lipca 2010 r. o szczególnych zasadach przygotowania do realizacji inwestycji w zakresie budowli przeciwpowodziowych; j) przedsięwzięć polegających na poszukiwaniu lub rozpoznawaniu złóż kopalin lub na wydobywaniu kopalin ze złóż, o których mowa w art. 10 ust. 1 Ustawy z dnia 9 czerwca 2011 r. - Prawo geologiczne i górnicze, prowadzonych na podstawie koncesji. Zob. art. 75 ust. 1 pkt 1 u.i.o.ś.

11 W przypadku inwestycji w zakresie budowy obiektu energetyki jądrowej i inwestycji towarzyszących realizowanej na podstawie Ustawy z dnia 29 czerwca 2011 r. o przygotowaniu i realizacji inwestycji w zakresie obiektów energetyki jądrowej oraz inwestycji towarzyszących. Zob. art. 75 ust. 1 pkt 1a u.i.o.ś.,

12 W przypadku scalania, wymiany lub podziału gruntów. Zob. art. 75 ust. 1 pkt 2 u.i.o.ś.,

13 W przypadku zmiany lasu, stanowiącego własność Skarbu Państwa, na użytek rolny. Zob. art. 75 ust. 1 pkt 3 u.i.o.ś. 
ne uregulowane w Dziale V Ocena oddziaływania przedsięwzięcia na środowisko oraz na obszar Natura 2000 u.o.i.ś. Wskazany dział reguluje:

- przypadki, kiedy przeprowadzenie oceny oddziaływania przedsięwzięcia na środowisko jest wymagane;

- treść i zakres raportu o oddziaływaniu przedsięwzięcia na środowisko;

- procedurę wydawania czy treść decyzji o środowiskowych uwarunkowaniach;

- zasady ponownego przeprowadzania oceny oddziaływania przedsięwzięcia na środowisko;

- przypadki kiedy przeprowadzenie oceny oddziaływania przedsięwzięcia na obszar Natura 2000 jest wymagane.

Zdefiniowany przez przepisy prawa zakres pojęcia „ocena oddziaływania na środowisko” odnosi się jedynie do postępowania administracyjnego prowadzonego zgodnie $\mathrm{z}$ zasadami określonymi w k.p. $a^{14}$ i przepisach odrębnych przez organy administracji publicznej. Przedstawiony powyżej rozwój procedury ocen oddziaływania na środowisko oraz jej przebieg w obecnym porządku prawnym wyraźnie ukazuje, iż z jednej strony nastąpił powrót do modelu, w którym to organ administracji obowiązany jest dokonać weryfikacji wniosku przedłożonego przez inwestora, a z drugiej nastąpiła ewolucja do procedury (nie samego dokumentu), w której wnioskodawca, wraz z organami wydającymi decyzje, opinie oraz społeczeństwem, wypracowuje rozwiązanie zawarte $\mathrm{w}$ decyzji o środowiskowych uwarunkowaniach realizacji przedsięwzięcia. W sytuacji, gdy wniosek nie jest przygotowywany przez podmiot o szczególnej pozycji (biegłego, rzeczoznawcę), a ocena oddziaływania na środowisko to procedura z udziałem wielu podmiotów, istotne staje się wyposażenie organu $\mathrm{w}$ informacje i zasady ich wykorzystywania gwarantujące właściwe przeanalizowanie wniosku oraz sformułowanie uwarunkowań.

Biorąc pod uwagę fakt, iż OOŚ jest sformalizowanym postępowaniem zakończonym władczym rozstrzygnięciem pań-

14 Ustawa z dnia 14 czerwca 1960 r. Kodeks postępowania administracyjnego, t.j. Dz.U. z 2013 r., poz. 267 ze zm. (dalej cyt.: k.p.a.). 
stwa, konieczne jest, aby dostępne dla organów administracji informacje oraz sposób ich wykorzystania były zgodne z przepisami dotyczącymi postępowania administracyjnego. Postępowanie administracyjne ${ }^{15}$ wymaga posługiwania się zasadami określonymi w k.p.a. Wśród zasad ogólnych postępowania administracyjnego na szczególną uwagę zasługują zasady:

- praworządności (art. 6 k.p.a. - zobowiązujący organy administracji publicznej do działania na podstawie przepisów prawa);

- prawdy obiektywnej (art. 7 k.p.a. - w myśl którego organy podejmują wszelkie czynności niezbędne do dokładnego wyjaśnienia stanu faktycznego oraz do załatwienia sprawy, mając na względzie interes społeczny i słuszny interes obywateli),

- pogłębiania zaufania do organów Państwa (art. 8 k.p.a. zgodnie z którym organy administracji publicznej prowadzą postępowanie w sposób budzący zaufanie jego uczestników do władzy publicznej);

- przekonywania (art. 11 k.p.a. - zmuszający organy administracji publicznej do wyjaśnienia stronom zasadność przesłanek, którymi kierują się przy załatwieniu sprawy, aby $\mathrm{w}$ ten sposób, w miarę możności, doprowadzić do wykonania przez strony decyzji bez potrzeby stosowania środków przymusu).

Powyższe zasady, obok przesłanek merytorycznych dotyczących samej procedury oceny oddziaływania na środowisko, uzasadniają ciągły rozwój środków i narzędzi stosowanych przez organy administracji możliwych do wykorzystania jako dowód $\mathrm{w}$ postępowaniu administracyjnym. Zgodnie z art. $75 \S 1$ k.p.a. jako dowód należy dopuścić wszystko, co może przyczynić się do wyjaśnienia sprawy, a nie jest sprzeczne z prawem. W szczególności dowodem mogą być dokumenty, zeznania świadków, opinie biegłych oraz oględziny. Wynika z tego, że organy mają znaczną dowolność w zakresie postępowania dowodowego, ale

15 Rozumiane jako postępowanie przed organami administracji publicznej w należących do właściwości tych organów sprawach indywidualnych rozstrzyganych w drodze decyzji administracyjnych. Zob. art. 1 pkt 1 k.p.a. 
z drugiej strony są zobowiązane przestrzegać zasad zmierzających do możliwie najlepszego i obiektywnego rozstrzygania spraw. Należy zatem oczekiwać, iż organy administracji winny poszukiwać nowych rozwiązań, szczególnie w tak wrażliwych kwestiach jak OOŚ czy szeroko rozumiana ochrona środowiska. Współcześnie rozwijające się społeczeństwo geoinformacyjne (Gaździcki 2004) dysponuje takimi rozwiązaniami, które mogą spełnić wymienione wyżej wymagania stawiane organom administracji. Preferowaną możliwością winny być systemy geoinformacyjne, które dostarczają danych, procedur i narzędzi do obiektywizacji podejmowanych decyzji środowiskowych. W tym kontekście działania takie można nazwać wsparciem geoinformacyjnym administracji rządowej, a także samorządowej.

\section{INFRASTRUKTURA INFORMACJI PRZESTRZENNEJ JAKO PODSTAWA GEOINFORMACYJNEGO WSPARCIA OOŚ}

Geoinformacja jako pojęcie pojawiło się w nauce pod koniec XX wieku jako efekt dyskusji na temat rozumienia GIS, ang. Geographical Information Systems - systemy informacji geograficznej, (Goodchild 1992) oraz jego różnych przekształceń w języku polskim (Zwoliński 2009). Zbigniew Zwoliński, omawiając rozwój myśli geoinformacyjnej, zdefiniował geoinformację jako naukę redefiniującą i rozwijającą dotychczasowe, uznane oraz przyjęte koncepcje, teorie, poglądy nauk geograficznych w kategoriach informatycznych, dające nowe możliwości interpretacyjne. Z kolei J. Gaździcki (2004) definiuje geoinformację jako: 1) informację uzyskiwaną na drodze interpretacji danych geoprzestrzennych lub 2) synonim, a także często używany skrót informacji geograficznej, stosowany również dla podkreślenia interdyscyplinarnego charakteru tego terminu nieograniczającego się do geografii jako nauki.

Powyższe definicje zdają się jednak nie oddawać znaczenia pojęcia geoinformacja użytego jako przymiotnik ,geoinformacyjne", dlatego też należy je dookreślić i wyjaśnić, iż wsparcie geoinformacyjne to pomoc przy użyciu systemów in- 
formacji geograficznej rozumianych jako zinstytucjonalizowana technologia informacji, która składa się z narzędzi umożliwiających zbieranie, przechowywanie oraz dowolne odzyskiwanie, przetwarzanie, prezentowanie danych przestrzennych, ale i nieprzestrzennych o świecie rzeczywistym, umiejscowionych geograficznie oraz z procedur dających odpowiedzi na stawiane pytania o interesujących użytkownika obiektach w systemie baz danych (Zwoliński 1994). Definicja ta opiera się na wcześniejszych definicjach Burruogh'a (1986) oraz Maguire'a (1991).

Rozważanie geoinformacyjnego wsparcia ocen oddziaływania na środowisko możliwe stało się dopiero od momentu implementacji Dyrektywy 2007/2/WE Parlamentu Europejskiego i Rady z dnia 14 marca 2007 r., ustanawiającej infrastrukturę informacji przestrzennej we Wspólnocie Europejskiej (INSPIRE) ${ }^{16}$. Proces ten jednak trwa nadal, co z jednej strony uniemożliwia pełne wdrożenie idei, ale daje także możliwości wskazywania kierunków niezbędnych zmian w procedurze ocen oddziaływania na środowisko. Z uwagi na istotność przedmiotowego okresu przejściowego owej doby implementacji Dyrektywy INSPIRE niezbędne jest wskazanie dat granicznych.

Moment ten rozpoczął się z wejściem w życie Dyrektywy INSPIRE, a upłynie wraz $\mathrm{z}$ ostatecznym terminem przeniesienia jej postanowień i wytycznych do prawa krajowego państw członkowskich. Dyrektywa, zgodnie z art. 25, weszła w życie w dniu 15 maja 2007 r., a w myśl art. 7 ust. 3 Dyrektywy w dniu 15 grudnia 2017 r. ${ }^{17}$ upływa ostateczny termin udostępniania usług informacji przestrzennej w odniesieniu do zbiorów i usług danych przestrzennych utworzonych przed wejściem w życie przepisów. Dziesięcioletni okres pomiędzy wejściem w życie, a udostępnieniem zbiorów i usług wynika z faktu, iż - w myśl

16 Dz. Urz. UE L 108 z 25.4.2007, s. 1 (dalej cyt.: Dyrektywy INSPIRE).

17 Na mapie drogowej Dyrektywy INSPIRE wskazuje się datę 10 listopada 2021 r. jako termin kiedy wszystkie usługi danych przestrzennych będą zgodne z załącznikiem VI i (w miarę możliwości) VII Rozporządzenia Komisji (UE) nr 1089/2010 z dnia 23 listopada 2010 r. w sprawie wykonania Dyrektywy 2007/2/WE Parlamentu Europejskiego i Rady w zakresie interoperacyjności zbiorów i usług danych przestrzennych. Źródło: http://inspire.ec.europa.eu/ index.cfm/pageid/44. 
art. 288 Traktatu o funkcjonowaniu Unii Europejskiej ${ }^{18}$ - dyrektywa wiąże każde państwo członkowskie, do którego jest kierowana, w odniesieniu do rezultatu, który ma być osiągnięty, pozostawia jednak organom krajowym swobodę wyboru formy i środków. Przepis powyższy oznacza, że okres implementacji (wykonania, realizacji, wprowadzenia w życie) to czas pomiędzy wejściem w życie aktu implementowanego, a chwilą, gdy jego litera i duch będą miały pełne odzwierciedlenie w porządku prawnym państwa członkowskiego. Pojęcie implementacji jest pojęciem szerszym aniżeli transpozycja (przełożenie). Termin transpozycji Dyrektywy INSPIRE został wskazany w jej art. 24 ust. 4, zgodnie z którym państwa członkowskie zostały zobowiązane do wprowadzenia w życie przepisów ustawowych, wykonawczych i administracyjnych niezbędnych do wykonania dyrektywy najpóźniej w terminie do 15 maja 2009 r. Polska wypełniła obowiązek transpozycji uchwalając w dniu 4 marca 2010 r. Ustawę o infrastrukturze informacji przestrzennej ${ }^{19}$, która weszła w życie w dniu 7 czerwca 2010 r. Wskazana ustawa wraz z ustanowionymi już rozporządzeniami Ministra Spraw Wewnętrznych i Administracji (w sprawie Rady Infrastruktury Informacji Przestrzennej ${ }^{20}$, w sprawie ewidencji zbiorów i usług danych przestrzennych objętych infrastrukturą informacji przestrzennej ${ }^{21}$ ) oraz aktami wykonawczymi Komisji Europejskiej (Rozporządzeniami: nr 1089/2010 z dnia 23 listopada 2010 r. w sprawie wykonania Dyrektywy 2007/2/WE Parlamentu Europejskiego i Rady w zakresie interoperacyjności zbiorów i usług danych przestrzennych ${ }^{22}$; nr 268/2010 z dnia 29 marca 2010 r. wykonujące dyrektywę 2007/2/WE Parlamentu Europejskiego i Rady w odniesieniu do dostępu instytucji i organów Wspólnoty do zbiorów oraz usług danych przestrzennych państw członkowskich zgodnie ze zharmonizowanymi warunkami ${ }^{23}$;

\footnotetext{
18 Dz.U. z 2004 r. Nr 90, poz. 864/2 (dalej cyt. TFUE).

19 Dz.U. z 2010 r. Nr 76, poz. 489 ze zm.

20 Dz.U. Nr 183, poz. 1233.

21 Dz.U. Nr 201, poz. 1333.

22 Dz. Urz. UE L 323 z 8.12.2010 ze zm.

23 Dz. Urz. UE L 83 z 30.3.2010.
} 
nr 976/2009 z dnia 19 października 2009 r. w sprawie wykonania Dyrektywy 2007/2/WE Parlamentu Europejskiego i Rady w zakresie usług sieciowych ${ }^{24}$; nr 1205/2008 z dnia 3 grudnia 2008 r. w sprawie wykonania Dyrektywy 2007/2/WE Parlamentu Europejskiego i Rady w zakresie metadanych ${ }^{25}$ oraz decyzją nr 2009/442/WE z dnia 5 czerwca 2009 r. w sprawie wykonania Dyrektywy 2007/2/WE Parlamentu Europejskiego i Rady w zakresie monitorowania i sprawozdawczości ${ }^{26}$ ) transponują postanowienia Dyrektywy INSPIRE do polskiego porządku prawnego. Powyższe nie zapewniło jednak pełnej implementacji, która jeszcze trwa.

Dyrektywa INSPIRE została ustanowiona w oparciu o art. 175 ust. 1 w zw. z art. 174 Traktatu ustanawiającego Wspólnotę Europejską (obecnie odpowiednio art. 192 ust. 1 w zW. z art. 191 TFUE), a więc już u jej podstaw były cele „środowiskowe”:

- zachowania, ochrony i poprawy jakości środowiska naturalnego;

- ochrony zdrowia ludzkiego;

- ostrożnego i racjonalnego wykorzystywania zasobów naturalnych;

- promowania na płaszczyźnie międzynarodowej środków zmierzających do rozwiązywania regionalnych lub światowych problemów środowiska naturalnego.

Kwestie przyświecające prawodawcy unijnemu zostały wyraźnie wskazane w preambule Dyrektywy INSPIRE. Na szczególną uwagę zasługują punkty 3, 4, 6, 11, 12, 15, 21 i 22 jej preambuły, które wskazują na przyczyny ustanowienia dyrektywy jako całości oraz przyjętych rozwiązań (zapisów), a także na możliwość i zasadność wykorzystania regulowanej przez nią infrastruktury informacji przestrzennej w ocenach oddziaływania na środowisko.

W punkcie 3 wskazano, iż z uwagi na występujące problemy dotyczące możliwości uzyskania, jakości, organizacji, dostępności, a także wspólnego korzystania z informacji prze-

24 Dz. Urz. UE L 274 z 20.10.2009 ze zm.

25 Dz. Urz. UE L 326 z 4.12.2008.

26 Dz. Urz. UE L 148 z 11.6.2009. 
strzennej napotykane przez organy administracji na różnych poziomach, niezbędne było podjęcie działań nastawionych na wymianę, wspólne korzystanie, dostęp oraz użytkowanie interoperacyjnych danych przestrzennych, usług dotyczących danych przestrzennych na różnych szczeblach administracji, ale też $\mathrm{w}$ różnych sektorach.

W myśl punktu 4 infrastruktura informacji przestrzennej w Unii Europejskiej (INSPIRE) winna wspomagać tworzenie polityki w odniesieniu do działań mogących mieć bezpośredni lub pośredni wpływ na środowisko. Myśl ta bezsprzecznie spójna jest z instytucją ocen oddziaływania przedsięwzięcia na środowisko, albowiem oceny wywierają pośredni wpływ na środowisko ustalając ramy dla inwestora.

Łatwe wyszukiwanie dostępnych danych przestrzennych, ocena ich przydatności dla określonego celu oraz możliwość zapoznania się z warunkami dotyczącymi ich wykorzystywania to cele stawiane infrastrukturze informacji przestrzennej w państwach członkowskich w punkcie 6 preambuły.

Prawodawca unijny w punkcie 11 preambuły wskazał na już istniejące oraz możliwe do utworzenia połączenia pomiędzy infrastrukturą informacji przestrzennej w Unii Europejskiej (INSPIRE) a innymi podejmowanymi inicjatywami mającymi na celu gromadzenie, harmonizację lub organizację rozpowszechniania lub wykorzystania informacji przestrzennych. Wśród możliwych połączeń wskazano:

- decyzję Komisji 2000/479/WE z dnia 17 lipca 2000 r. w sprawie wdrożenia europejskiego rejestru emisji zanieczyszczeń (EPER), zgodnie z art. 15 Dyrektywy Rady 96/61/WE dotyczącej zintegrowanego zapobiegania zanieczyszczeniom i ich kontroli (IPPC) ${ }^{27}$,

- bazę danych CORINE land cover,

- bazę danych Europejskiego Systemu Informacji o Polityce Transportowej ETIS.

Parlament Europejski i Rada zaznaczyły w punkcie 12, iż dyrektywa powinna mieć zastosowanie do danych przestrzennych przechowywanych przez administrację lub w jej imieniu

27 Dz. Urz. UE L 192 z 28.7.2000, s. 36. 
oraz do wykorzystywania danych przestrzennych przy wykonywaniu jej zadań publicznych.

Unijny prawodawca zauważył w punkcie 15, że główną przeszkodą dla pełnego wykorzystania dostępnych danych jest czasochłonność i kosztowność poszukiwania istniejących danych przestrzennych lub sprawdzanie, czy mogą one być użyte $\mathrm{w}$ danym celu. Rozwiązaniem powyższego problemu ma być nałożony na państwa członkowskie obowiązek dostarczenia opisów dostępnych zbiorów danych przestrzennych oraz usług $\mathrm{w}$ formie metadanych.

Kolejnym punktem preambuły uzasadniającym istotność dyrektywy dla geoinformacyjnego wsparcia ocen oddziaływania na środowisko jest punkt 21, w którym Parlament Europejski i Rada wskazały, że dla udostępnienia informacji pochodzącej od organów administracji różnego szczebla niezbędne jest usunięcie występujących w praktyce przeszkód w tym zakresie, na jakie natrafiają one przy wykonywaniu swoich funkcji publicznych mogących mieć bezpośredni lub pośredni wpływ na środowisko.

Autorzy dyrektywy podnieśli w kolejnym, 22 punkcie, iż należy podjąć działania zmierzające do zapobiegania sytuacji, w której doraźne negocjacje między organami utrudniłyby dostęp do odpowiednich zbiorów danych przestrzennych i usług przy wykonywaniu zadań przez owe organy.

Dyrektywa INSPIRE stanowi niezbędny element uzupełniający możliwość geoinformacyjnego wsparcia ocen oddziaływania na środowisko, a dopiero po jej pełnej implementacji będzie możliwe bezpośrednie wykorzystywanie systemów informacji geograficznych, jako metody oraz narzędzia obiektywizującego działania organów administracyjnych.

Zarówno Dyrektywa INSPIRE, jak również ustawa wprowadzają katalog tematów danych przestrzennych w zakresie których istnieje obowiązek tworzenia, ale też utrzymywania zbiorów danych.

Zbiory danych przestrzennych winny spełniać następujące warunki:

- odnosić się do terytorium Rzeczypospolitej Polskiej;

- występować w postaci elektronicznej; 
- być utrzymywane przez:

1) organ administracji lub w jego imieniu, które zgodnie z jego zadaniami publicznymi są tworzone, aktualizowane i udostępniane;

2) osobę trzecią, której umożliwiono włączenie się do infrastruktury;

- należeć co najmniej do jednego z tematów danych przestrzennych określonych $\mathrm{w}$ załączniku do ustawy.

Organy administracji prowadzące rejestry publiczne, które zawierają zbiory związane $\mathrm{z}$ wymienionymi w załączniku do ustawy tematami danych przestrzennych, mają obowiązek tworzenia i obsługi w zakresie swojej właściwości, sieci usług dotyczących zbiorów oraz usług danych przestrzennych. Organy prowadzące rejestry obowiązane są do nieodpłatnego udostępniania innym organom administracji, w zakresie niezbędnym do realizacji przez nie zadań publicznych, posiadanych zbiorów.

Porównanie katalogu tematów danych przestrzennych, o których mowa powyżej, z treścią art. 3 ust. 1 pkt 5 u.i.o.ś. określającego treść Karty informacyjnej, wskazuje, iż organ korzystając z narzędzi geoinformacyjnych - będzie mógł zweryfikować znaczną część Karty.

Tematy danych przestrzennych, przydatne do weryfikacji Karty ująć, można podzielić na grupy. Po pierwsze są to tematy użyteczne $\mathrm{w}$ celu weryfikacji danych o rodzaju, skali i usytuowaniu przedsięwzięcia, obejmujące następujące punkty w ramach rozdziału 1 załącznika do Ustawy z 2010 r., tj. pierwszej grupy tematycznej: pkt 1 - systemy odniesienia za pomocą współrzędnych, rozumiane jako systemy do jednoznacznego, przestrzennego odnoszenia informacji przestrzennej za pomocą współrzędnych $\mathrm{x}, \mathrm{y}$, z lub za pomocą szerokości czy długości geograficznej oraz wysokości na podstawie geodezyjnego poziomego i pionowego układu odniesienia; pkt 2 - systemy siatek georeferencyjnych, rozumiane jako systemy tworzone na podstawie zharmonizowanej, wielorozdzielczej siatki o znormalizowanym położeniu, wielkości oczek oraz wspólnym punkcie początkowym; pkt 3 - nazwy geograficz- 
ne rozumiane jako nazwy obszarów, regionów, miejscowości, miast, przedmieść lub osiedli, a także nazwy innych obiektów geograficznych lub topograficznych o znaczeniu publicznym lub historycznym; pkt 4 - jednostki administracyjne rozumiane jako jednostki zasadniczego trójstopniowego podziału terytorialnego państwa; pkt 5 - adresy rozumiane jako informacje o lokalizacji nieruchomości na podstawie danych adresowych, zazwyczaj nazwy miejscowości, nazwy ulicy, numeru budynku i kodu pocztowego; pkt 6 - działki ewidencyjne rozumiane jako ciągłe obszary gruntu znajdującego się w granicach jednego obrębu ewidencyjnego, jednorodne pod względem prawnym, wydzielone z otoczenia za pomocą linii granicznych.

Po drugie tematy przydatne dla celów weryfikacji danych o powierzchni zajmowanej nieruchomości, a także obiektu budowlanego oraz dotychczasowym sposobie ich wykorzystywania i pokryciu nieruchomości szatą roślinną, które ujęte są w następujących punktach rozdziału 2 (pkt 2 - użytkowanie ziemi rozumiane jako fizyczne, a także biologiczne użytkowanie powierzchni ziemi, włączając $w$ to powierzchnie naturalne i sztuczne, obszary rolnicze, lasy, tereny podmokłe, akweny), rozdziału 3 załącznika do Ustawy z 2010 r.: pkt 2 - budynki rozumiane jako informacje o lokalizacji przestrzennej budynków; pkt 3 - gleba rozumiana jako gleby i podglebie charakteryzowane na podstawie głębokości, tekstury, struktury, zawartości cząstek oraz materiału organicznego, kamienistości, erozji, a w odpowiednich przypadkach na podstawie przeciętnego nachylenia czy przewidywanej zdolności zatrzymywania wody; pkt 4 - zagospodarowanie przestrzenne rozumiane jako zagospodarowanie terenu $\mathrm{w}$ jego obecnym lub przyszłym wymiarze funkcjonalnym albo przeznaczenie społeczno-gospodarcze terenu, $\mathrm{w}$ tym mieszkaniowe, przemysłowe, handlowe, rolnicze, leśne, wypoczynkowe, wynikające z dokumentów planistycznych; pkt 8 - obiekty produkcyjne i przemysłowe rozumiane jako zakłady przemysłowe oraz urządzenia poboru wody, miejsca wydobycia i składowiska; pkt 11 - gospodarowanie obszarem, strefy ograniczone i regulacyjne oraz jednostki sprawozdawcze rozumiane jako obszary zarządzane, regulowane lub wykorzystywane do celów sprawozdawczych 
na poziomie międzynarodowym, europejskim, krajowym, regionalnym i lokalnym; obejmują również wysypiska śmieci, obszary o ograniczonym dostępie wokół ujęć wody pitnej, strefy zagrożone przez azotany, uregulowane drogi wodne na morzach lub wodach śródlądowych o dużej powierzchni, obszary przeznaczone pod składowiska odpadów, strefy ograniczeń hałasu, obszary wymagające zezwolenia na poszukiwania, wydobycie, obszary dorzeczy, odpowiednie jednostki sprawozdawcze czy obszary zarządzania strefą brzegową.

Po trzecie tematy przydatne dla celów weryfikacji danych o możliwym transgranicznym oddziaływaniu na środowisko, które ujęte są w następujących punktach w ramach rozdziału 1 Ustawy z 2010 r.: pkt 1 - systemy odniesienia za pomocą współrzędnych rozumiane jako systemy do jednoznacznego, przestrzennego odnoszenia informacji przestrzennej przy udziale współrzędnych x, y, z lub szerokości i długości geograficznej oraz wysokości na podstawie geodezyjnego poziomego i pionowego układu odniesienia; pkt 4 - jednostki administracyjne rozumiane jako jednostki zasadniczego trójstopniowego podziału terytorialnego państwa; pkt 9 - obszary chronione postrzegane jako obszary wyznaczone lub zarządzane $\mathrm{w}$ ramach prawa międzynarodowego, europejskiego prawa wspólnotowego lub prawa państw członkowskich Wspólnot Europejskich w celu osiągnięcia szczególnych celów ochrony.

Mając na względzie powyższe wyjaśnienia, należy wskazać, iż rozumienie wsparcia geoinformacyjnego w OOŚ winno brzmieć: „Zasady i metody interpretacji danych geograficznych, w kategoriach informatycznych, służących dostarczaniu argumentów lub dowodów niezbędnych w postępowaniach administracyjnych, w zakresie ocen oddziaływania przedsięwzięć na środowisko oraz na obszary Natura 2000, w stanie prawnym obowiązującym po wejściu w życie: ustawy o infrastrukturze informacji przestrzennej i przepisów wykonawczych do niej oraz przepisów wykonawczych do dyrektywy INSPIRE". 


\section{PODSUMOWANIE}

Przedstawiony powyżej rozwój ocen oddziaływania na środowisko oraz podstawy prawne infrastruktury informacji przestrzennej wyraźnie wskazują na potrzebę trwałego włączenia do postępowań administracyjnych w zakresie ocen lub wydania decyzji o środowiskowych uwarunkowaniach systemów geoinformacji. Wsparcie geoinformacyjne, funkcjonujące $\mathrm{w}$ oparciu o Dyrektywę INSPIRE, pozwoli organom administracji na wydawanie rozstrzygnięć opartych na rzetelnych i mających podstawy prawne danych przestrzennych.

\section{BIBLIOGRAFIA}

Burrough P. A., Principles of Geographic Information Systems for Land Resources Asessment, Clarendon, Oxford 1986.

Ciechelska A., Oceny oddziaływania jako narzędzie realizacji zrównoważonego rozwoju, Białystok 2009.

Council on Environmental Quality Executive Office of the President, A Citizen's Guide to the NEPA. Having Your Voice Heard, 2007 [online] http://www.blm.gov/style/medialib/blm/nm/programs/ planning/planning_docs.Par.53208.File.dat/A_Citizens_Guide_ to_NEPA.pdf [dostęp: 16 maja 2015].

Gaździcki J., Internetowy leksykon geomatyczny, 2004 [online], http:// www.ptip.org.pl/ [dostęp: 16 maja 2015].

Jendrośka J., Ocena oddziaływania na środowisko. Fachowa ekspertyza czy procedura z udziałem społeczeństwa. Sytuacja w Polsce na tle tendencji światowych, Wrocław 1997.

Maguire D. J., An overview and definitione of GIS, w: Geographical information systems, vol. 1, Principles, red. D. J. Maguire, M. F. Goodchild, D. W. Rhind, London 1991.

Nowakowski T., Podedworna-Łuczak M., Raport o oddziaływaniu na środowisko dróg i autostrad: poradnik prawno-metodyczny, Warszawa 2009.

Synowic A., Rzeszot U., Oceny oddziaływania na środowisko, Poradnik, Instytut Ochrony Środowiska, Warszawa 1995.

Zbierska J., Geneza idei i edukacji zrównoważonego rozwoju, „Fragmenta Agronomica" 2007, rok XXIV, nr 4(96) [online] http://www. 
up.poznan.pl/pta/pdf/Fragm.\%20Agron.\%20vol.\%2024\%20 (2007)/36-\%20FA\%2024(4)\%202007\%20-Zbierska.pdf [dostęp: 16 maja 2015].

Zwoliński Z., Zastosowanie Systemu Informacji Geograficznej w realizacji Zintegrowanego Monitoringu Środowiska Przyrodniczego, w: Sympozjum Zintegrowany Monitoring Środowiska Przyrodniczego, Funkcjonowanie i monitoring ekosystemów, Jodłowy DwórŚwięty Krzyż 1994.

Zwoliński Z., Rozwój myśli geoinformacyjnej, w: GIS - platforma integracji geografii, red. Z. Zwoliński, Poznań 2009.

Kontakt e-mail:

marcin.kazmierski@amu.edu.pl 